\title{
Prevention of Sourdough Bread Spoliage by Antifungal Lactic Acid Bacteria Fermentation
}

\author{
Zühal Alkay ${ }^{1 *}$, Hilal Kılmanoğlu ${ }^{2}$, Muhammed Zeki Durak ${ }^{3 \dagger}$ \\ ${ }^{1 *}$ Yildiz Technical University, Faculty of Chemical and Metallurgical Engineering and Department of Food Engineering 34210, Esenler, Istanbul, Turkey (ORCID: \\ 0000-0002-2420-3369) \\ ${ }^{2}$ Yildiz Technical University, Faculty of Chemical and Metallurgical Engineering and Department of Food Engineering 34210, Esenler, Istanbul, Turkey (ORCID: \\ 0000-0003-0561-4653) \\ $3^{*}$ Yildiz Technical University, Faculty of Chemical and Metallurgical Engineering and Department of Food Engineering 34210, Esenler, Istanbul, Turkey (ORCID: \\ 0000-0001-7245-1116)
}

(İlk Geliş Tarihi 12 Kasım 2019 ve Kabul Tarihi 29 Şubat 2020)

(DOI: 10.31590 /ejosat.646043)

ATIF/REFERENCE: Alkay, Z., Kılmanoğlu, H. \& Durak, M. Z. (2020). Prevention of Sourdough Bread Spoliage by Antifungal Lactic Acid Bacteria Fermentation. Avrupa Bilim ve Teknoloji Dergisi, (18), 379-388.

\section{$\ddot{\mathbf{O z}}$}

Fırıncılık ürünleri arasında önemli bir yere sahip olan ekmeğin, kısa sürede tüketilmesini gerektiren en büyük neden küflenmedir. Ekmekte küflenmenin engellenmesi için laktik asit bakterilerinin kullanımı yapılan çalışmalar arasındadır. Ekşi hamur ekmeği, laktik asit bakterisi (LAB) ve maya arasındaki etkileşimle oluşan geleneksel bir ürün olmaktadır. Ekşi hamur fermentasyonunda meydana gelen laktik asit, asetik asit ve alkol, ester, karbonil gibi uçucu bileşikler hamurdaki mikroorganizmalar tarafından üretilmektedir. Ekşi hamur kullanımının, ticari maya kullanılarak elde edilen ürünlerden daha fazla lezzet, daha iyi reoloji ve depolama özelliklerine sahip olduğu bilinmektedir. Bu bağlamda yapılan çalışmada, 12 farklı LAB suşunun antifungal aktivitesi ve bu aktivitenin ekşi hamur ve ekmek üzerindeki sonuçları incelenmiştir. Lb. brevis 28C1B3, Lb. plantarum 59E1B4, Lb. crustorum 34TB6N, Lb. brevis 34TB2M, Lb. numerensis 34TB1M, Lb. paralimentarius 5901B2 suşlarının en iyi antifungal aktiviteye sahip olduğu tespit edilmiştir. Lb. brevis 28C1B3 suşunun en iyi proteolitik aktiviteye sahip olduğu görülmüştür. Ekşi hamurdan saflaştırılan EPS'lerin tümü glukan yapıda olmuştur. Son olarak ekşi hamur ekmeklerinin kontrollü küflendirilmesi ile antifungal analiz sonucu arasında paralellik gözlemlenmiştir. Bu çalışma ile ekşi hamur laktik asit bakteri izolatlarının ekmeğin kalite kriterlerini olumlu yönde etkilediğini göstermiştir.

Anahtar Kelimeler: Ekşi hamur ekmeği, Laktik asit bakterisi, Antifungal aktivite

\section{Prevention of Sourdough Bread Mould Spoliage by antifungal Lactic Acid Bacteria Fermentation}

\begin{abstract}
Bread has an important place among bakery products. Also, the mold is the biggest reason that requires consumed in a short period of time. The use of lactic acid bacteria to inhibit mold growth in breads are among the studies performed. Sourdough bread is a traditional product formed by the synergistic interaction of lactic acid bacteria (LAB) and yeasts. Lactic acid, acetic acid and various volatile compounds such as ester, alcohol, aldehydes, furan derivates which occur in the sourdough fermentation, are produced by yeast and bacteria in the dough. It is known that the application of sourdoughs provides more flavor, better rheology, and storage properties than products obtained using commercial yeast. In this study, antifungal activities of 12 different LAB strains and the results of this activity on sourdough and breads were investigated. It was determined that Lb. brevis 28C1B3, Lb. plantarum 59E1B4, Lb. crustorum 34TB6N, Lb. brevis 34TB2M, Lb. numerensis 34TB1M, Lb paralimentarius 59O1B2 strains had the best antifungal activity. The Lb. brevis $28 \mathrm{C} 1 \mathrm{~B} 3$ strain was found to have the best proteolytic activity. All EPSs purified from sourdough were glucan. Finally, a parallelism was observed between controlled mold molding of sourdough bread and antifungal analysis. With this study, sourdough lactic acid bacterial isolates have shown that it affects the quality criteria of bread positively.
\end{abstract}

Keywords: Sourdough bread, Lactic acid bacteria, Antifungal activity

\footnotetext{
1* Sorumlu Yazar: Yildiz Technical University, Faculty of Chemical and Metallurgical Engineering and Department of Food Engineering 34210, Esenler, Istanbul, Turkey ORCID: 0000-0002-2420-3369, zuhalalkay21@,hotmail.com

${ }^{3 \dagger}$ Sorumlu Yazar: Yildiz Technical University, Faculty of Chemical and Metallurgical Engineering and Department of Food Engineering 34210 , Esenler, Istanbul, Turkey, ORCID: 0000-0001-7245-1116, mzdurak@yildiz.edu.tr
} 


\section{Introduction}

Bread making is one of the oldest skills still accepted by mankind (Pétel et al., 2017). Sourdough bread industry technology is gaining importance due to the food quality criteria such as nutritional development, shelf life, production of digestible and delicious foods. The main characteristics of leavened white bread are parameters such as high volume and shelf life, microbiologically safe, good nutritional and sensory properties (Chavan and Jana, 2008; Mildner - Szkudlarz and Bajerska, 2016). Because of these properties, deterioration caused by bacteria and molds is delayed (Behera and Ray, 2016; Gänzle et al., 2008). Because, the economic loss caused by bread mold is large. Therefore, varius methods such as the addition of chemical preservatives, various packaging methods and the use of sourdough are being tried. The use of sourdough which is an alternative method for bread production is a natural method besides improving the textural and aromatic properties, which increases the consumer demand (Yan et al., 2016; Axel et al., 2016).

Sourdough bread is called a traditional product with high nutraceutical factors resulting from the positive interaction and biochemical reactions of yeast and lactic acid bacteria (LAB) (Gobbetti, 1998). The use of sour dough fermented with LAB, an alternative to the commonly used additives in bread processing and selected as a strong bioprotective agent, has been supported by several studies. Garofalo et al., (2012) isolated mold from bread and looked at the in vitro antifungal properties of LAB isolates against these molds and confirmed that they have these antifungal properties. Sourdough is formed by fermentation of homo and heterofermantative LAB by mixing flour and water. Because of the concentration of lactic acid and acetic acid is increased in the mixture, the taste resulting from fermentation is sour (El Sheikha and Mahmoud, 2016; Vrček et al., 2014). Antimicrobial compounds formed by lactic acid bacteria in the sourdough system include acetic and lactic acid (Corsetti and Settanni, 2007), cyclic dipeptides, phenyllactic acid (Lavermicocca et al., 2003; Ström et al., 2002) and hydroxy fatty acids (Black et al., 2013; Schnürer and Magnusson, 2005; Ström et al., 2002). However, the concentrations of most of these antimicrobial compounds produced are too low to be a conservation strategy alone. The antifungal effect of sourdough cannot be said to be directly related to pH (Debonne et al., 2018). However, organic acids in sourdough such as $\mathrm{pH}$, acetic and lactic acid affect the degree of activation of several antifungal activities. Also, during sourdough fermentation occur acidification, proteolysis and enzyme activation. LAB in the sourdough have proteolytic activity and the ability to release acids and small peptides from wheat proteins. These processes lead to biochemical changes that affect dough and bakery products positively. Thus, it improves the nutritional and functional quality of bakery products (Gobbetti et al., 2014; Gocmen et al., 2007; Hadaegh et al., 2017). One of the main metabolic activities of LAB species in sourdough is the production of exopolysaccharide (EPS). EPSs affect the technological properties of sourdough and sourdough bread and EPS produced by LAB is used to improve the textural properties of fermented foods (De Vuyst and Degeest, 1999).

The aim of the study is to determine the proteolytic activity of different lactic acid bacteria, the monosaccharides of EPSs from sourdoughs made with these LABs, and the textural properties of sourdough bread. Our study is important for the textural properties of sourdough made with different starters. For this purpose, It was evaluated the effects on the quality of sourdough bread such as controlled moldy, determination of proteolytic activity, determination of sugar amount. Our study is important for the textural properties of sourdough made with different starters.

\section{Material and Methods}

\subsection{Method}

\subsubsection{Microorganism Strains and culture conditions}

Firstly, for the isolation of yeast and lactic acid bacteria from the collected traditional sourdough samples, cultivation was carried out on their suitable media. After all strains performed DNA extraction, they were identified by $16 \mathrm{~S}$ rRNA sequencing. While the lactic acid bacteria strains selected to this study were Lb. crustorum 34TB6N, Lb. paracasei 39CB11, Lb. numerensis 34TB1M, Lb. koreensis 34BB5, Lb. plantarum 59E1B4, W. cibaria 37KB2, Lb. brevis 28C1B3, Lb. paracasei 61TB8, Lb. numerensis 78STB4, Lb. brevis 34TB2M, Lb. paralimentarius 59O1B2, Lb. plantarum 39LB2, selected yeast was Saccharomyces pastorium HM3. These strains were maintained in glycerol at $-80{ }^{\circ} \mathrm{C}$ until used. The medium used for the reproduction of pure bacteria culture was MRS (De Man Rogosa Sharpe) medium and incubated at $37^{\circ} \mathrm{C}$ for 24 hours under anaerobic conditions. Yeast recovery was in culture medium Sabouraud dextrose broth at $30^{\circ} \mathrm{C}$ for 24 hours.

Fungal strains (Penicillium carneum, Aspergillus flavus, Aspergillus niger and Alternaria) isolated from moulded bread samples. These strains were cultivated on PDA (potato dextrose agar) at $25^{\circ} \mathrm{C}$ for $72 \mathrm{~h}$.

\subsubsection{Determination of antifungal activity of $L A B$}

The inhibitory effects of lactic acid bacteria isolated from sourdough on bread molds were investigated. Suspensions of lactic acid bacteria developed in MRS broth were adapted to $10^{7}$ colony-forming units (CFU) / $\mathrm{ml} .5 \mu$ l of strains grown in broth were then placed on the MRS agar plates and plates were incubated for $48 \mathrm{~h}$ at $37{ }^{\circ} \mathrm{C}$ under anaerobic condition. After cooling prepared soft PDA, mold was inoculated into sterile conditions. The plates were overlaid with $10 \mathrm{ml}$ of soft PDA containing $10^{4} \mathrm{cfu} / \mathrm{ml}$ molds. The plates were incubated for $72 \mathrm{~h}$ at $25^{\circ} \mathrm{C}$ and then, measurement of inhibition zone diameter around the bacterial spots was conducted (Mauch et al. 2010). This experiment was performed in duplicate to ensure the accuracy of the results. 


\subsubsection{Proteolytic activity}

The antifungal metabolites formed during sourdough fermentation differ according to the type of bacteria and the substrates used by them. One of the factors affecting the antifungal properties of lactic acid bacteria is the metabolites that are released by breaking down the amino acids in the medium. Therefore, determining the level of their proteolytic activity can be examined relationship with antifungal properties. The proteolytic activities of the isolates of lactic acid bacteria were performed as described by Axel et al. (2016). For this purpose, a modified medium containing $28 \mathrm{~g} / 1$ skim milk powder, $5 \mathrm{~g} / 1$ casein peptone, $2.5 \mathrm{~g} / 1$ yeast extract, $1 \mathrm{~g} / 1$ glucose and $15 \mathrm{~g} / 1$ agar was prepared. The clear zones formed by the bacteria developed in the modified medium were measured and experiment was performed twice.

\subsubsection{Sourdough preparation}

In present study, three different sourdough was prepared. Two different lactic acid bacteria were used for each sourdough fermentation. These bacteria were chosen because of their high antifungal and proteolytic activity properties and are shown in Table 1. Apart from LAB strains ( $0.2 \mathrm{~g}$ per each one bacteria), the ingredients used are $0.2 \mathrm{~g}$ of yeast, $75 \mathrm{~g}$ of water, $100 \mathrm{~g}$ of flour and prepared sourdough fermented for $24 \mathrm{~h}$ at $30^{\circ} \mathrm{C}$. Lactic acid bacteria and yeast cell counts, total titratable acidity (TTA) and pH values of sourdough samples were determined at the beginning and end of fermentation.

\subsubsection{Microbiological analysis}

Microbiological analysis of sourdough samples were determined according to Gül et al. (2005). The determination of the bacterial population was carried out after completion of sourdough fermentation. Briefly, the samples was homogenised in proportion 1:9 sourdough to $0.85 \%$ (w/v) sterilised physiological saline (FTS) (Merck, Germany) solution in stomacher. Obtained serial dilutions plated onto MRS agar and Sabouraud dextrose agar, the plates were incubated at $37^{\circ} \mathrm{C}$ for $1-2$ day.

\subsubsection{Acidity measurements}

The total acidity (\% lactic acid) of the sourdoughs acidity was determined by volumetric method (Erbaş, 2003) and $\mathrm{pH}$ was measured using the (WTW Inolab 7110) $\mathrm{pH}$ meter.

\subsubsection{Purification of EPS in sourdough}

The sourdough sample was weighed and 2:1 ratio of ultrapure water was added. After dissolution, centrifuge at $5000 \times$ rpm for 20 min. The supernatant removed after centrifugation was mixed with $96 \%$ cold ethanol (twice the supernatant). The mixtures stored for $24 \mathrm{~h}$ at $4{ }^{\circ} \mathrm{C}$. Collapsed material was collected by centrifugation at $5{ }^{\circ} \mathrm{C}$ for $20 \mathrm{~min}$ at $5000 \times \mathrm{rpm}$. The pellet was dissolved in deionized water, and then 2 times of cold ethanol was added and and the same centrifugation conditions were applied to mixture. The purified EPS was frozen at $-80^{\circ} \mathrm{C}$. After the obtained EPS was lyophilized, it was analyzed by HPLC (Van Geel-Schutten et al., 1999).

\subsubsection{Determination of sugar content of sourdoughs}

In this context, approximately $0.1 \mathrm{~g}$ of sample was mixed with $0.5 \mathrm{M} 25 \mathrm{~mL}$ of sulfuric acid and incubatied at $95^{\circ} \mathrm{C}$ for 12 hours. Then $\mathrm{pH}$ of mixture was adjusted to 7 with $4 \mathrm{M} \mathrm{NaOH}$. After centrifugation at $8000 \times \mathrm{rpm}$ for 10 minutes and the supernant was removed and passed through $0.22 \mu \mathrm{m}$ pore size filter. The prepared samples were injected into the high-pressure liquid chromatography (HPLCRID, Shimadzu) system with RID-10A refractive index detector. Injection volume was determined as $20 \mu 1$ and CARBOsep CHO-682 $\mathrm{Pb}$ was used as column. The flow rate was adjusted to $0.7 \mathrm{~mL} / \mathrm{min}$. The column temperature was kept constant at $25^{\circ} \mathrm{C}$ and deionized water was used as mobile phase. Sugars such as glucose, sucrose, fructose, xylose, arabinose were used to create the standard calibration curve (Ispirli and Dertli, 2018).

\subsubsection{Production of sourdough breads}

Three doughs were prepared using previously prepared three different sourdough. Bread doughs include $60 \mathrm{~g}$ water, $3 \mathrm{~g}$ salt, 2.75 $\mathrm{g}$ gluten. It also consists of two times the total weight of the sourdough ( $220 \mathrm{~g}$ wheat flour, $110 \mathrm{~g}$ sourdough). The shaped doughs were left to fermentation for 2 hours. After the doughs were fermented baked at $210^{\circ} \mathrm{C}$ for 30 minutes. LAB strains used in bread preparation are shown in Table 1. 
Table 1. Bacterial and yeast combinations used in sourdough breads

\title{
Strains codes
}

\author{
Bread 1 \\ Lb. brevis (22), Lb. plantarum (11), Saccharomyces pastorium (HM3) \\ Bread 2 \\ Lb. crustorum (4), Lb. brevis (31), Saccharomyces pastorium (HM3) \\ Bread 3 \\ Lb. numerensis (13), Lb. paralimentarius (33), Saccharomyces pastorium (HM3) \\ Control \\ Lb. plantarum 39LB2, Lb. brevis 28C1B3, Saccharomyces pastorium HM3
}

\subsubsection{Controlled mold of breads}

Penicillium carneum, Aspergillus flavus, Aspergillus niger and Alternaria were used to mold the bread. This assay was performed to determine the antifungal effect of LAB strains on these molds after baking bread. Briefly, $10 \mu \mathrm{L}$ from suspension of $10^{6} \mathrm{conidia} / \mathrm{mL}$ of mold was placed on the bread slice. The plastic boxes containing the slices were incubated at room temperature for 10 days. Slices were checked daily in terms of mold growth and colony diameters were measured (Suhr and Nielsen, 2003).

\subsubsection{Texture analysis}

Texture profile analysis was performed to evaluate the hardness or staling of the breads produced. The textural properties of the breads were measured by the Texture Analyzer TA Plus after the breads were cooked and cooled. The analysis was carried out with a $35 \mathrm{~mm}$ cylinder probe on, a approach speed of $55 \mathrm{~mm} / \mathrm{min}$, a compression ratio of $25 \%$ and a maximum load of $50 \mathrm{~N}$. Bread were tested by cutting a $2.5 \mathrm{~cm}$ height. The results were carried out in triplicate and recorded (Mohamed et al., 2008).

\subsubsection{Statistical analysis}

All data obteined in this study were represented as mean \pm standard deviation using SPSS statistical software (SPSS for Windows ver. 22.0). Evaluation of significant differences was performed with ANOVA and Tukey post-hoc tests. All differences were considered significant at $\mathrm{P}<0.05$.

\section{Results and Discussion}

\subsection{Antifungal activity}

Mostly microbiological deterioration of breads is caused by mold formation. In particular, mold species such as Penicillium spp. and Aspergillus spp. cause bread spoilage (Gerez et al., 2009; Legan, 1993). In addition, bacterial disruption (Sorokulova et al., 2003) and yeast disruption (Deschuyffeleer et al., 2011) may occur with rope formation. Mold formation is very important for the shelf life of bread. Therefore, LABs are used as a fermentation agent in bakery applications to improve the specific properties of bread and to obtain dough acidity (Gobbetti et al., 2014; Hammes and Gänzle, 1998). Because LABs produce metabolites with antifungal activity. However, antifungal metabolites are not approved in foods and have been said to adversely affect the taste of bread (Axel et al., 2017; Black et al., 2013; Quattrini et al., 2018). Acetic acid is produced in primary carbohydrate metabolism and has antifungal activity. It also has an effect on the taste and texture of the bread (Drews, 1959; Gerez et al.,2009; Kaditzky et al.,2008). The in situ protective effects of LAB have often been attributed to the synergistic activity of compounds that are not characterized (Axel et al., 2017; Mandel et al., 2013).

Therefore, antifungal activity of $12 \mathrm{LAB}$ isolated from sourdough was determined in our study. The antifungal activities of LAB isolated from sourdough against A. niger, A. flavus, P. carneum were determined (Table 1). İn general, overall the LAB strains showed no antifungal effect on $P$. carneum and $A$. alternata, since no zones were formed in the petri where these molds were inoculated. Among LAB strains, which have the most inhibitory effect against $A$. niger were seen as $L$. brevis 28C1B3, L. plantarum 59E1B4 and $L$. plantarum 39LB2. LAB having inhibitory effect on A. flavus were identified as L. plantarum 59E1B4 and L. plantarum 39LB2. At the same time, the strain L. paracasei 39CB11 and L. numerensis 78STB4 of these bacteria showed no inhibitory effect against any of the identified molds. LAB with high antifungal activity were selected for further studies. Within the heterofermentative group of LAB, such as $L$. brevis, displays a high degree of antifungal activity owing to its production of a mixture of organic acids. These acids were reported to have synergistic inhibitory effects on species of Fusarium, Penicillium, Aspergillus. Obviously, LAB have the potential to be used in food preservation to prevent mold growth in general, and have specific antifungal activity against fungi isolated from bread (Kam et al., 2007). 
Table 1. Antifungal activity of sourdough lactic acid bacteria

\begin{tabular}{|c|c|c|c|c|}
\hline Types of Bacteria & $\begin{array}{l}\text { Penicillium } \\
\text { carneum }\end{array}$ & $\begin{array}{l}\text { Aspergillus } \\
\text { flavus }\end{array}$ & $\begin{array}{l}\text { Aspergillus } \\
\text { niger }\end{array}$ & $\begin{array}{c}\text { Alternaria } \\
\text { alternata }\end{array}$ \\
\hline (4) Lb. crustorum 34TB6N & - & $8.0 \pm 0.0^{\mathrm{A}}$ & $6.05 \pm 0.07^{\mathrm{a}}$ & - \\
\hline (7) Lb. paracasei 39CB11 & - & - & - & - \\
\hline (13) Lb. numerensis 34TB1M & - & $8.05 \pm 0.07^{\mathrm{A}}$ & $6.05 \pm 0.07^{\mathrm{a}}$ & - \\
\hline (17) Lb. koreensis 34BB5 & - & - & $2.1 \pm 0.14^{\mathrm{b}}$ & - \\
\hline (11) Lb. plantarum 59E1B4 & - & $8.05 \pm 007^{\mathrm{A}}$ & $10.05 \pm 0.07^{\mathrm{c}}$ & - \\
\hline (21) W. cibaria $37 \mathrm{~KB} 2$ & - & - & $8.07 \pm 0.1^{\mathrm{d}}$ & - \\
\hline (22) Lb. brevis $28 \mathrm{C} 1 \mathrm{~B} 3$ & - & $2.05 \pm 0.07^{\mathrm{B}}$ & $12.05 \pm 0.07^{\mathrm{e}}$ & - \\
\hline (24) Lb. paracasei $61 \mathrm{~TB} 8$ & - & - & $6.05 \pm 0.07^{\mathrm{a}}$ & - \\
\hline (29) L. numerensis 78STB4 & - & - & - & - \\
\hline (31) Lb. brevis $34 \mathrm{~TB} 2 \mathrm{M}$ & - & $6.05 \pm 0.07^{\mathrm{C}}$ & $2.05 \pm 0.07^{b}$ & - \\
\hline (33) Lb. paralimentarius 5901B2 & - & $4.1 \pm 0.14^{\mathrm{D}}$ & $2.1 \pm 0.14^{\mathrm{b}}$ & - \\
\hline Lb. plantarum 39LB2 & - & $8.0 \pm 0.0^{\mathrm{A}}$ & $10.0 \pm 0.0^{\mathrm{c}}$ & - \\
\hline
\end{tabular}

${ }^{\mathrm{a}-\mathrm{e}}$ Means followed by different lowercase letters represent significant differences for the inhibition on A.niger of each bacteria

A-D Means followed by different lowercase letters represent significant differences for the inhibition on A.flavus of each bacteria

\section{2. pH, TTA and microbiological characteristics of sourdoughs}

Table 2 shows the number of LAB and yeast in sourdough samples at 0 and 24 hours, while Table 3 shows the pH and TTA (\% lactic acid) values. In this study, 39LB2-28C1B3-HM3 combination was chosen as a control sourdough sample. Initially, the LAB and yeast counts in sourdough samples were determined as 7.98 and $5.78 \mathrm{log} \mathrm{cfu} / \mathrm{g}$ respectively. The LAB and yeast counts were determined as 9.4 and $7.1 \log \mathrm{cfu} / \mathrm{g}$ after the $24 \mathrm{~h}$ of the fermentation. The least bacteria growth was found in the sourdough sample Lb. crustorum + Lb. brevis $+S$. pastorium (4-31-HM3), while the most bacteria growth was in the samples prepared by the culture combination of $S$. pastorium + Lb. brevis + Lb. plantarum (39LB2-28C1B3-HM3) but the difference between the dough is not statistically significant. The highest increase in the number of yeast among the doughs is 1 and 3 coded dough and difference is statistically significant.

Table 2. Lactic acid bacteria and yeast count (log cfu / g)

\begin{tabular}{lcccc}
\hline \multirow{2}{*}{ Sourdough Code } & \multicolumn{2}{c}{ 0 $^{\text {th }}$} & \multicolumn{2}{c}{ 24 $^{\text {th }}$} \\
\cline { 2 - 5 } & Lactobacilli & Yeast & Lactobacilli & Yeast \\
\hline $\mathbf{1 ( 2 2 - 1 1 - H M 3 ) ~}$ & $7.93 \pm 0.33$ & $5.00 \pm 0.03$ & $9.34 \pm 0.01^{\mathrm{b}}$ & $7.17 \pm 0.03^{\mathrm{B}}$ \\
$\mathbf{2 ( 4 - 3 1 - H M 3 )}$ & $7.72 \pm 0.03$ & - & $9.14 \pm 0.06^{\mathrm{bc}}$ & $7.50 \pm 0.01^{\mathrm{C}}$ \\
$\mathbf{3 ( 1 3 - 3 3 - H M 3 )}$ & $7.91 \pm 0.01$ & $5.20 \pm 0.01$ & $9.25 \pm 0.05^{\mathrm{a}}$ & $7.25 \pm 0.01^{\mathrm{B}}$ \\
Control(39LB2-28C1B3- & $7.98 \pm 0.33$ & $5.78 \pm 0.01$ & $9.44 \pm 0.05^{\mathrm{c}}$ & $7.08 \pm 0.03^{\mathrm{A}}$ \\
HM3) & & & & \\
\hline
\end{tabular}

$0^{\text {th }}: 0$. hour of fermentation, $24^{\text {th }}: 24$. hour of fermentation

a-c Means followed by different lowercase letters represent the significant difference in the change in the number of Lactobacilli in different doughs

A-C Means followed by different lowercase letters represent the significant difference in the change in the number of yeast in different doughs

LAB and yeast count of sourdough samples varied according to fermentation condition. At the end of the fermentation, the yeast count was low in the sourdough sample with high LAB count and Coda et al. (2018) who stated that the lactic acid bacteria increase as a result of sourdough fermentation.

The improvements in sensory and functional properties of bread as a result of the symbiotic relationship between yeast and LAB, sourdough attracts the attention of many researchers (De Vuyst and Neysens, 2005; Galle and Arendt, 2014). LAB synthesize lactic acid by homofermentation of hexose, lactose and acetic acid, ethanol and $\mathrm{CO}_{2}$ by heterofermentation of hexose. They affect the acidity of 
sourdough. The LAB led to the decrease of $\mathrm{pH}$ values of sourdough. Also, with the enzymatic activities of LAB, the proteins are hydrolyzed and the free amino acid rate is increased (Hansen and Schieberle, 2005) and thus may cause higher TTA.

With the production of organic acids by LABs, titratable acidity (TTA) increases. Thus, the $\mathrm{pH}$ of the dough decreases. Measurement of total organic acids synthesized during dough fermentation is called TTA value (Brandt, 2007). There was an inverse correlation between PH and tta. TTA value decreases with increasing $\mathrm{pH}$. Acidification kinetic parameters of sourdoughs made from the mixed starters in our results are given in Table 3. Initially, the $\mathrm{pH}$ values were between 5-6, and at the end of the 24th hour, these values became 3 . In addition, the $\mathrm{pH}$ values at the end of the 24 th hour were similar. The lower $\mathrm{pH}$ of the control group is probably due to the mixture of selected LAB strains. Here, Lb. plantarum and Lb. brevis strains produced more lactic and acetic acid in particular, resulting in a more effective $\mathrm{pH}$ reduction in the sourdough. In our results, it is seen that $\mathrm{pH}$ and TTA values overlap with each other and the lowest $\mathrm{pH}$ value has control sourdough. The other sourdough groups had a similar $\mathrm{pH}$ value at the end of 24 hours. The highest $\mathrm{pH}$ reduction and acidity increase occurred in the 2 coded dough and is statistically significant.

Table 3. Acidity measurements of sourdough samples

\begin{tabular}{lcccc}
\hline \multirow{2}{*}{ Sourdough Code } & \multicolumn{2}{c}{$\mathbf{0}^{\text {th }}$} & \multicolumn{2}{c}{$\mathbf{2 4}^{\text {th }}$} \\
\cline { 2 - 5 } & pH & $\begin{array}{c}\text { TTA (\%lactic } \\
\text { acid) }\end{array}$ & Ph & $\begin{array}{c}\text { TTA (\%lactic } \\
\text { acid) }\end{array}$ \\
\hline $\mathbf{1 ( 2 2 - 1 1 - H M 3 ) ~}$ & $5.94 \pm 0.01$ & $0.17 \pm 0.00$ & $3.46 \pm 0.007^{\mathrm{a}}$ & $1.25 \pm 0.00^{\mathrm{b}}$ \\
$\mathbf{2 ( 4 - 3 1 - H M 3 )}$ & $6.00 \pm 0.01$ & $0.18 \pm 0.00$ & $3.46 \pm 0.030^{\mathrm{b}}$ & $1.31 \pm 0.00^{\mathrm{b}}$ \\
$\mathbf{3 ( 1 3 - 3 3 - H M 3 )}$ & $5.27 \pm 0.01$ & $0.29 \pm 0.00$ & $3.46 \pm 0.007^{\mathrm{c}}$ & $1.26 \pm 0.00^{\mathrm{a}}$ \\
Control(39LB2-28C1B3- & $5.55 \pm 0.01$ & $0.17 \pm 0.00$ & $3.39 \pm 0.030^{\mathrm{d}}$ & $1.18 \pm 0.00^{\mathrm{a}}$ \\
HM3) & & & & \\
\hline
\end{tabular}

TTA: titratable acidity, $0^{\text {th }}: 0$. hour of fermentation, $24^{\text {th }}: 24$. hour of fermentation

a-d Means followed by different lowercase letters represent the significant difference in the change of $\mathrm{pH}$ in different doughs

A-B Means followed by different lowercase letters represent the significant difference in the change of TTA in different doughs

\subsection{Determination proteolytic activity}

LAB have a large number of amino acid auxotrophs and depend on the nutritional requirements for amino acids (Kunji et al., 1996). Many sourdough lactobacilli do not have extracellular proteinase activity (Pepe et al., 2003; Vermeulen et al., 2005). Wheat and rye proteinase activity promotes the growth of non-proteolytic lactobacilli. Extracellular protease activity is known to improve the orgaleptic properties of yeasty bakery products and these properties are achieved by producing small peptides and free amino acids as precursors for taste development (Cagno et al. 2002; Rizzello et al. 2014).In addition, extracellular protease activity produces small peptides necessary for acidification and rapid microbial growth during fermentation (Cagno et al. 2002). In addition, the release of bioactive peptides from proteins that are thought to play a role in improving health of certain LAB strains are among the known properties (Leroy et al. 2006).These inventions have demonstrated the use of these LABs in bread making.

The protease activity of 12 lactic acid bacteria used in the study is examined. As shown in Figure 1, it has been determined that LABs have different protease activities with different zone diameters. The highest activity among these lactic acid bacteria strains was 22 (28C1B3-Lb. brevis) and the lowest activity was strain 24 (61TB8-Lb. paracasei). Axel et al. (2016), the results of our study was supported by giving the conclusion that Lactobacillus has proteolytic activity.

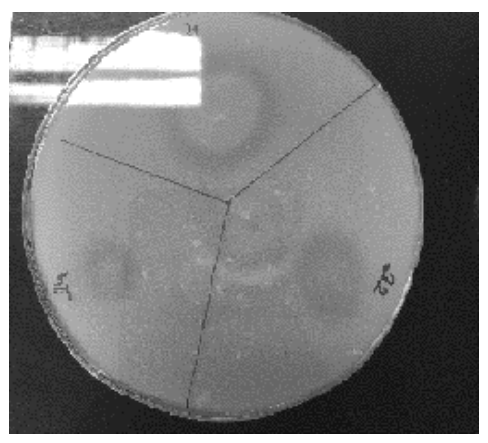

Figure 1. Proteolytic activity of some lactic acid bacteria on milk agar (21: 37KB2-W. cibaria, 22: 28C1B3-Lb. brevis, 24: 61TB8-Lb. paracasei) 


\subsection{Determination of sugar in sourdough by HPLC}

EPSs are long chain polysaccharides produced by microorganisms using various sugars as substrates (Galle and Arendt, 2014; Welman and Maddox, 2003). It is generally composed of branched or repetitive units of sugar and sugar derivatives (Welman and Maddox, 2003). Based on its chemical composition, the EPS may consist of one or two different sugar units. Homopolysaccharide (glucose, fructose) is a type of sugar composed of two different sugar units called heteropolysaccharide (galactose, rhamnose) (Galle and Arendt, 2014). EPS can be used as an anti-staling additive to increase the quality and shelf life of breads (Lynch et al., 2018).

In our results, sour dough was produced with different LAB types and sugars in EPS structure were determined by HPLC. Glucose and fructose were found in all sourdough varieties. In addition, sucrose, arabinose and xylose were not detected. All LAB species produced EPS in the glucan structure and EPSs differed in quantity due to the LAB starters used in sour dough. However, we evaluated sugar groups as present or absent. All EPSs produced by LABs in our study have homopolysaccharide character in glucan structure.

\subsection{Determination of Controlled mold of breads}

As mentioned previously, it has been reported that the acetic and lactic acids produced by LAB as well as the phenolic acids produced by these bioactive strains exhibit antifungal activity due to their low $\mathrm{pH}$. In addition to organic acids, it has been shown to be the source of antifungal activity in other secondary metabolites produced by LAB (Moore et al., 2008; Crowley et al., 2013; Ahlberg et al., 2015; Hassan et al., 2005). Therefore, in order to protect bakery products from mold spores, it is necessary to either use sourdough with antifungal activity or to use modified atmospheres techniques, ethanol and fungal inhibitors such as propionic, sorbic, benzoic and acetic acids (Legan 1993, Rocken 1996). It is seen that LAB contribute to increase the shelf life of bread since it produces these fungal inhibitors. In our study, the mold zones showed similarity.

In our study, the controlled mold sourdough was kept in plastic containers at room temperature for 10 days. Mold growth was observed at the end of the 7th day. The sourdough was approximately the same as the antifungal activity values of LAB isolates (Table 5). However, A. alternata mold developed in 3rd sourdough bread in controlled mold. We also made 39LB2-28C1B3-HM3 sourdough was used as control. In addition, commercial leavened bread (2.5\%) was made to show the difference between them. The results showed that commercial yeast bread generally had the highest mold zone measurement. In addition, our control sourdough bread and 4 sour dough bread showed similar mold formation. It was observed that sourdough bread had a higher shelf life compared to commercial bread.

Table 5. Controlled mold results of breads $(\mathrm{mm})$

\begin{tabular}{lcccc}
\hline \multicolumn{1}{c}{ Sample Code } & $\begin{array}{c}\text { Penicillium } \\
\text { carneum }\end{array}$ & Aspergillus flavus & Aspergillus niger & Alternaria \\
\hline 1.dough bread & - & $14.0 \pm 0.00$ & $15.0 \pm 0.00$ & - \\
2.dough bread & - & $15.0 \pm 0.00$ & $15.0 \pm 0.00$ & - \\
3.dough bread & - & $14.0 \pm 0.00$ & $15.0 \pm 0.00$ & $8.5 \pm 0.00$ \\
Commercial yeast bread & - & $17.0 \pm 0.00$ & $15.0 \pm 0.00$ & $10.0 \pm 0.00$ \\
Control(39LB2-28C1B3- & - & $14.0 \pm 0.00$ & $15.0 \pm 0.00$ & - \\
HM3) & & & & \\
\hline
\end{tabular}

\subsection{Bread texture analysis}

While the hardness of the breads 1 and 2 from the prepared sourdough was lower than the control sourdough bread, it was seen that the hardness of the bread numbered 3 was higher than the control. Springiness and resilience values were higher than control bread and chewiness and gumminess values were lower (Table 6).

Table 6. Texture profile analysis of the prepared breads (mean \pm Std.)

\begin{tabular}{lcccccc}
\hline & Hardness(N) & Springiness & Cohesiveness & Gumminess & Chewiness & Resilience \\
\hline Control & $7.26 \pm 0.34$ & $0.91 \pm 0.00$ & $0.85 \pm 0.01$ & $5.87 \pm 0.46$ & $5.32 \pm 0.42$ & $0, .55 \pm 0.02$ \\
Bread 1 & $4.11 \pm 0.19$ & $0.96 \pm 0.02$ & $0.87 \pm 0.00$ & $4.01 \pm 0.54$ & $3.84 \pm 0.52$ & $0.59 \pm 0.01$ \\
Bread 2 & $5.25 \pm 0.24$ & $0.95 \pm 0.02$ & $0.86 \pm 0.00$ & $4.32 \pm 0.34$ & $4.08 \pm 0.31$ & $0.59 \pm 0.00$ \\
Bread 3 & $6.17 \pm 0.07$ & $0.93 \pm 0.02$ & $0.84 \pm 0.01$ & $5.20 \pm 0.00$ & $4.90 \pm 0.04$ & $0.57 \pm 0.01$ \\
Commercial & $2.44 \pm 0.22$ & $1.73 \pm 0.22$ & $0.89 \pm 0.01$ & $2.10 \pm 0.27$ & $3.60 \pm 0.09$ & $0.61 \pm 0.01$ \\
yeast bread & & & & & & \\
\hline
\end{tabular}


The lower hardness of breads 1 and 2 may result from differences in the biological acidification and amino acid use of the strains used in those breads. Hadaegh et al. (2017), the use of sourdough reduces the hardness and organic acids as a result of the enzymatic activation of lactic acid bacteria, acidity is said to increase. Thanks to the increased acidity, it is stated that the solubility of gluten is increased and the hardness decreases. Bread 3 is harder and it's can be because amount of EPS in sourdough 3 is low and this may be the decrease in bread volume (Tamani et al., 2013). According to the results of the texture analysis, it is seen that $2.5 \%$ commercial yeast bread has a softer structure than the sourdough. The reason for this may be interpreted as the gas produced by the metabolism of the yeast may cause to increase the bread volume and decrease the hardness (Ronda et al., 2015).

\section{Conclusion}

This study demonstrated effect of some LAB on the textural, microbiological and quality properties of sourdough breads. The results showed that strains with the best antifungal activity among LABs were Lb. plantarum and Lb. brevis. Lactobacillus brevis strain has the best proteolytic activity. Monosaccharides contained of EPS in sourdough with different LAB and yeast combination have been glucose and fructose and the monosaccharides in the sourdough samples were the same. Also, it was observed that sourdough breads showed higher hardness values than commercial yeast breads. These are of great importance for future work.

\section{References}

Ahlberg, S. H., Joutsjoki, V., Korhonena, H. J. (2015). Potential of lactic acid bacteria in aflatoxin risk mitigation. International Journal of Food Microbiology, 207, 87-334 102.

Axel C., Brosnan B., Zannini E., Peyer L. C., Furey A., Coffey A., Arendt E. K. (2016). Antifungal activities of three different Lactobacillus species and their production of antifungal carboxylic acids in wheat sourdough. Applied Microbiology Biotechnology, 100, 1701-1711.

Axel, C., Zannini, E., Arendt, E.K., (2017). Mold spoilage of bread and its biopreservation: a review of current strategies for bread shelf life extension. Crit. Rev. Food Sci. Nutr. 57, 3528-3542.

Behera, S. S., \& Ray, R. C. (2016). Sourdough bread. In C. M. Rosell, J. Bajerska, \& A. F. El Sheikha (Eds.), Bread and its fortification (pp. 53-67). Boca Raton: CRC Press.

Black, B. A., Zannini, E., Curtis, J. M., \& Gï, M. G. (2013). Antifungal hydroxy fatty acids produced during sourdough fermentation: microbial and enzymatic pathways, and antifungal activity in bread. Appl. Environ. Microbiol., 79(6), 1866-1873.

Brandt MJ (2007) Sourdough products for convenient use in baking. Food Microbiol 24(2):161-164. https ://doi.org/10.1016/j. fm.2006.07.010

Chavan, R., \& Jana, A. (2008). Frozen dough for bread making - A review. International Journal of Food Science \& Technology, 2, 9 27. https://doi. org/10.3923/ijds.2010.113.127

Coda R., Xu Y., Morenoa D. S., Mojzitac D., Nionellia L., Rizzello C. G., Katina K. (2018). Performance of Leuconostoc citreum FDR241 during wheat flour sourdough type I propagation and transcriptional analysis of exopolysaccharides biosynthesis genes.Food microbiology 76:164-172. https://doi.org/10.1016/j.fm.2018.05.003.

Corsetti,A., \& Settanni, L. (2007). Lactobacilli in sourdough fermentation. Food Research International,40(5),539-558.

Crowley, S., Mahony, J., \& Van Sinderen, D. (2013). Current perspectives on antifungal lactic acid bacteria as natural bio-preservatives. Trends in Food Science \& Technology, 33, 93-109.

De Vuyst, L., \& Degeest, B. (1999). Heteropolysaccharides from lactic acid bacteria. FEMS Microbiology Reviews, $23(2), 153-177$.

De Vuyst, L., Neysens, P. (2005). The sourdough microflora: biodiversity and metabolic interactions. Trends Food Sci. Technol. 16, 43-56.

Debonne, E., Van Bockstaele, F., De Leyn, I., Devlieghere, F., \& Eeckhout, M. (2018). Validation of in-vitro antifungal activity of thyme essential oil on Aspergillus niger and Penicillium paneum through application in par-baked wheat and sourdough bread. LWT, 87, 368-378.

Deschuyffeleer, N., Audenaert, K., Samapundo, S., Ameye, S., Eeckhout, M., \& Devlieghere, F. (2011). Identification and characterization of yeasts causing chalk mould defects on par-baked bread. Food microbiology, 28(5), 1019-1027.

Di Cagno, R., De Angelis, M., Lavermicocca, P., De Vincenzi, M., Giovannini, C., Faccia, M., \& Gobbetti, M. (2002). Proteolysis by sourdough lactic acid bacteria: effects on wheat flour protein fractions and gliadin peptides involved in human cereal intolerance. Appl. Environ. Microbiol., 68(2), 623-633.

Drews, E. (1959). Der Einfluß gesteigerter Essigsäurebildung auf die Haltbarkeit des Schrotbrotes. Brot Gebäck, 13, $113-114$.

El Sheikha, A. F., \& Mahmoud, Y. A.-G. (2016). Bread fungal contamination: Risk of mycotoxins, protection of anti-fungal and need to fungal identification. In C. M. Rosell, J. Bajerska, \& A. F. El Sheikha (Eds.), Bread and its fortificationfor nutrition and health benefits (pp. 150-162). Boca Raton, FL: Science Publishers Inc., CRC Press.

Erbaş M., (2003). Yaş Tarhananın Üretim ve Farklı Saklama Koşullarında Bileşimindeki Değişmeler. Akdeniz Üniversitesi, Fen Bilimleri Enstitüsü, Antalya.

Galle, S., Arendt, E.K. (2014). Exopolysaccharides from sourdough lactic acid bacteria. Crit. Rev. Food Sci. Nutr. 54, 891-901.

Gänzle, M. G., Haase, G., \& Jelen, P. (2008). Lactose: Crystallization, hydrolysis and value-added derivatives. International Dairy Journal, 18(7), 685-694.https://doi.org/10.1016/j.idairyj. 2008.03. 003

Garofalo, C., Zannini, E., Aquilanti, L., Silvestri, G., Fierro, O., Picariello, G., \& Clementi, F. (2012). Selection of sourdough lactobacilli with antifungal activity for use as biopreservatives in bakery products. Journal of agricultural and food chemistry, 60(31), 77197728 
Gerez, C. L., Torino, M. I., Rollán, G., \& de Valdez, G. F. (2009). Prevention of bread mould spoilage by using lactic acid bacteria with antifungal properties. Food control, 20(2), 144-148.

Gobbetti, M. (1998). The sourdough microflora: Interactions of lactic acid bacteria and yeasts. Trends in Food Science \& Technology, 9(7), 267-274. https://doi.org/10.1016/S0924-2244(98)00053-3

Gobbetti, M., Rizzello, C.G., Di Cagno, R., De Angelis, M. (2014). How the sourdough may affect the functional features of leavened baked goods. Food Microbiology, 37, 30-40. https://doi.org/10.1016/ j.fm.2013.04.012

Gocmen D., Gurbuz O., Kumral A.Y., Dagdelen A.F., Sahin I. (2007). The effects of wheat sourdough on glutenin patterns, dough rheology and bread properties. European Food Research and Technology, 225: 821-830.

Gül H., Özçelik S., Sağdıç O., Certel M. (2005). Sourdough bread production with lactobacilli and S. cerevisiae isolated from sourdoughs. Process Biochemistry 40: 691-697

Hadaegh H, Seyyedain Ardabili S M, Tajabadi Ebrahimi M, Chamani M and Azizi Nezhad R. (2017). The Impact of different lactic acid bacteria sourdoughs on the quality characteristics of toast bread. Journal of Food Quality, 1-11.

Hammes, W.P., Gänzle, M.G., 1998. Sourdough breads and related products. In: Wood, B.J.B. (Ed.), Microbiology of Fermented Foods. Springer US, Boston, MA, pp. 199-216.

Hansen, A., and Schieberle, P. (2005). Generation of aroma compounds during sourdough fermentation: applied and fundamental aspects. Trends in Food Science \& Technology, 16(1), 85-94.

Hassan, Y., Zhou, T., \& Bullerman, L. B. (2005). Sourdough lactic acid bacteria as antifungal and mycotoxin-controlling agents. Food Science and Technology International, 22, 79-90.

Ispirli H. and Dertli E. (2018). Isolation and identification of exopolysaccharide producer lactic acid bacteria from Turkish yoğurt. J Food Process Preserv. 42:e13351. https://doi.org/10.1111/jfpp.13351

Kaditzky, S., Seitter, M., Hertel, C., Vogel, R.F., 2008. Performance of Lactobacillus sanfranciscensis TMW 1.392 and its levansucrase deletion mutant in wheat dough and comparison of their impact on bread quality. Eur. Food Res. Technol. $227,433-442$.

Kam, P. V., Bianchini, A., \& Bullerman, L. B. (2007). Inhibition of mold growth by sourdough bread cultures. RURALS: Review of undergraduate research in agricultural and life sciences, 2(1), 5.

Kunji, E. R., Mierau, I., Hagting, A., Poolman, B., \& Konings, W. N. (1996). The proteotytic systems of lactic acid bacteria. Antonie van Leeuwenhoek, 70(2-4), 187-221.

Lavermicocca, P., Valerio, F., \& Visconti, A. (2003). Antifungal activity of phenyllactic acid against molds isolated from bakery products. Appl. Environ. Microbiol., 69(1), 634-640.

Legan,J.D.(1993). Mould spoilage of bread: The problem and some solutions. International Biodeterioration \& Biodegradation,32(1),33-53.

Lynch, K. M., Coffey, A., \& Arendt, E. K. (2018). Exopolysaccharide producing lactic acid bacteria: Their techno-functional role and potential application in gluten-free bread products. Food Research International, 110, 52 -61.

Mandel, V., Sen, S.K., Mandel, N.C., 2013. Production and partial characterisation of an inducer-dependent novel antifungal compound(s) by Pediococcus acidilactici LAB 5. J. Sci. Food Agric. 93, 2445-2453.

Mauch A, Dal Bello F, Coffey A, Arendt EK. (2010). The use of Lactobacillus brevis PS1 to in vitro inhibit the out growth of Fusarium culmorum and other common Fusarium species found on barley. Int J Food Microbiol 141:116-21.

Mildner-Szkudlarz, I., \& Bajerska, J. (2016). Phytochemicals as functional bread compounds. In C. M. Rosell, J. Bajerska, \& A. F. El Sheikha (Eds.), Bread and its fortification for nutrition and health benefits (pp. 373-384). Boca Raton, FL: Science Publishers Inc., CRC Press.

Mohamed A., Rayas-Duarte P., Xu J. 2008. Hard Red Spring wheat/C-TRIM 20 bread: Formulation,processing and texture analysis. Food Chemistry, 107,516-524.

Moore, M.M., Dal Bello, F., \& Arendt, E.K. (2008). Sourdough fermented by Lactobacillus plantarum FST 1.7 improves the quality and shelf life of gluten-free bread. European Food Research and Technol, 226, 1309-1316.

Pepe, O., Villani, F., Oliviero, D., Greco, T., \& Coppola, S. (2003). Effect of proteolytic starter cultures as leavening agents of pizza dough. International journal of food microbiology, 84(3), 319-326.

Pétel, C., Onno, B., \& Prost, C. (2017). Sourdough volatile compounds and their contribution to bread: A review. Trends in Food Science \& Technology, 59, 105-123. https://doi.org/10.1016/j.tifs. 2016.10.015

Quattrini, M., Bernardi, C., Stuknytè, M., Masotti, F., Passera, A., Ricci, G., Vallone, L., De Noni, I., Brasca, M., Fortina, M.G., 2018. Functional characterization of Lactobacillus plantarum ITEM 17215: a potential biocontrol agent of fungi with plant growth promoting traits, able to enhance the nutritional value of cereal products. Food Res. Int. 106, 936-944.

Rizzello CG, Curiel JA, Nionelli L, Vincentini O, Di Cagno R, Silano M, Gobbetti M, Coda R (2014). Use of fungal proteases and selected sourdough lactic acid bacteria for making wheat bread with an intermediate content of gluten. Food Microbiol 37: 59-68. https://doi.org/10.1016/j.fm.2013.06.017

Rocken, W. (1996). Applied aspects of sourdough fermentation. Adv. Food Sci. 18:212-216.

Ronda F, Perez Quirce S, Lazaridou A, Billiaderis CG. (2015). Effect of barley and oat $\beta$-glucan concentrates on gluten-free ricebased doughs and bread characteristics. Food Hydrocolloids, 48, 197-207.

Schnürer, J., \& Magnusson, J. (2005). Antifungal lactic acid bacteria as biopreservatives. Trends in Food Science \& Technology, 16(13), 70-78.

Sorokulova, I. B., Reva, O. N., Smirnov, V. V., Pinchuk, I. V., Lapa, S. V., \& Urdaci, M. C. (2003). Genetic diversity and involvement in bread spoilage of Bacillus strains isolated from flour and ropy bread. Letters in applied microbiology, 37(2), $169-173$.

Ström, K., Sjögren, J., Broberg, A., \& Schnürer, J. (2002). Lactobacillus plantarum MiLAB 393 produces the antifungal cyclic dipeptides cyclo (L-Phe-L-Pro) and cyclo (L-Phe-trans-4-OH-L-Pro) and 3-phenyllactic acid. Appl. Environ. Microbiol., 68(9), 4322-4327. 
Suhr and Nielsen,(2003). Antifungal activity of essential oils evaluated by two different application techniques against rye bread spoilage fungi. Journal of Applied Microbiology 94, 665-674.

Tamani RJ, Goh K K T and Brennan C S. (2013). Physico-chemical properties of sourdough bread production using selected Lactobacilli starter cultures. Journal of Food Quality, 36, 245-252.

Van Geel-Schutten, G. H., Faber, E. J., Smit, E., Bonting, K., Smith, M. R., Ten Brink, B., Kamerling J.P., Vliegenthart, J. F. G. and Dijkhuizen L. (1999). Biochemical and Structural Characterization of the Glucan and Fructan Exopolysaccharides Synthesized by the Lactobacillus reuteri Wild-Type Strain and by Mutant Strains. Applied and Environmental Microbiology, 65(7), 3008-3014.

Vermeulen, N., Pavlovic, M., Ehrmann, M. A., Gänzle, M. G., \& Vogel, R. F. (2005). Functional characterization of the proteolytic system of Lactobacillus sanfranciscensis DSM 20451T during growth in sourdough. Appl. Environ. Microbiol., 71(10), 6260-6266.

Vrček, I. V., Čepo, D. V., Rašić, D., Peraica, M., Žuntar, I., Bojić, M., ... \& Medić-Šarić, M. (2014). A comparison of the nutritional value and food safety of organically and conventionally produced wheat flours. Food chemistry, 143, 522-529.

Welman, A. D., \& Maddox, I. S. (2003). Exopolysaccharides from lactic acid bacteria: Perspectives and challenges. Trends in Biotechnology, 21(6), 269-274.

Yan B., Zhao J., Fan D., Tian F., Zhang H., Chen W. (2016). Antifungal activity of Lactobacillus plantarum against Penicillium roqueforti in vitro and the preservation effect on chinese steamed bread. Journal of Food Processing and Preservation, 41, 1-9. 